\title{
Greater water availability increases the water use efficiency and productivity of corn and bean species grown in secondary crop systems
}

\author{
Felipe Schwerz ${ }^{1}$, Braulio Otomar Caron ${ }^{1}$, Elvis Felipe Elli ${ }^{1}$, John Robert Stolzle ${ }^{1}$, Elder Eloy ${ }^{1}$, Denise \\ Schmidt $^{1}$, Luciano Schwerz ${ }^{1}$, Velci Queiróz de Souza ${ }^{2}$
}

\author{
${ }^{1}$ Federal University of Santa Maria, Frederico Westphalen Campus, 98400-000, Frederico Westphalen, Rio \\ Grande do Sul, Brazil \\ ${ }^{2}$ Federal University of Pampa, Don Pedrito Campus, 96450-000, Don Pedrito, Rio Grande do Sul, Brazil
}

*Corresponding author: eloyelder@yahoo.com.br

\begin{abstract}
Secondary crop cultivation is very important for producers of corn and beans crops worldwide, and can reach high levels of productivity. The study aimed to evaluate water use efficiency and grain yield response of corn and bean species cultivated in a secondary crop system, when subjected to different water levels. Two experiments were carried out, one for the corn cultivar DKB 240 and another for the bean cultivar IPR Gralha; the study was developed in an experimental area classified as Oxisol typical, both experimental designs consisted of a randomized single factor block design with five water levels $(0,50,75,100$ and $125 \%$ of reference evapotranspiration; Eto) with three replications. The following variables were analyzed: number of rows per ear, number of grain per row, thousand grain mass and grain yield for corn; number of pods per plant, number of seeds per pod, thousand grains mass and grain yield for beans. Water use efficiency was calculated as the relationship between grain yield and the applied water level. The corn and bean crops had the highest water use efficiency in the levels of $100 \%$ and $125 \%$ of reference evapotranspiration, respectively. These levels showed the highest yield of crops. Both corn and beans can be recommended for planting in the second crop system as they present a high yield potential under favorable water conditions; in order to meet water demands, they require a total of $413.53 \mathrm{~mm}$ for corn and $447.12 \mathrm{~mm}$ for the bean cultivar distributed throughout the crop cycle.
\end{abstract}

Keywords: water deficit, reference evapotranspiration, Phaseolus vulgaris L., Zea mays L., meteorological variables.

Abbreviations: Ca_calcium; Mg_magnesium; CEC_cation exchange capacity; DAE_days after emergence; Eto_reference evapotranspiration; K_potassium; P_phosphorus; N_nitrogen; NRE_number of rows per ear: NGR_number of grains per row; NPP_number of pods per plant; NSP_number of seeds per pod; TGM_thousand grain mass; pH_potential of hydrogen ions; WL_water level; WUE_water use efficiency.

\section{Introduction}

The production of corn (Zea mays L.) for human and animal consumption is a basic widespread activity of most rural agricultural properties in Brazil; black beans (Phaseolus vulgaris L.) are one of the most balanced foods in terms of nutrient and energy content. Because of the nutrient and energy content of these plants, they are one of the primary sources of energy and protein in the diets of a majority of the population (Soratto et al., 2015). Both species were chosen for this analysis due to their socio-economic importance.

Secondary crop cultivation is a widely adopted methodology and is important for regional farmers as well as national production; plants grown in this system can reach high levels of productivity and thus are the focus of current research (Cruz et al., 2011). A practical result of this research has led to a significant change in cropping techniques; in the last three years, the production of corn in the secondary crop system surpassed the production of this crop in primary plantation systems during the summer (CONAB, 2014).

Corn and beans are well adapted to tropical and subtropical regions with high availability of water, nutrients and solar radiation, which have high yield potential. In the secondary crop set up, the production of these plants is affected, because they are subject to periods of water stress that can happen due to irregular rainfall, and severe limitations of solar radiation, and temperatures in different growth stages. Water is a factor of utmost importance in secondary crop systems for corn and beans. Under stress conditions, physiological responses of plants are negatively impacted, resulting in a lower degree of productivity and consequently yield. This response depends greatly upon the length, severity, and a plant's phenological stage during a drought (Iqbal et al., 2014; Zhang et al., 2007). The determination of water use efficiency is one way to analyze the response of cultures in different conditions of water availability, because this variable relates crop yield with the amount of water applied or that has evapotranspired (Puppala et al., 2005). The growth and development of these plants is impacted in drought conditions.

Numerous studies show the importance of efficient use of water by crops. Franks et al. (2015), discuss improvements in crop water-use efficiency (WUE) as a critical priority for regions facing increased drought or diminished groundwater resources, they also affirm the need to develop new strategies to increase WUE. According to Franks et al. (2015), an alternative is to increase the stomatal density of plants through genetic improvement. Han et al. (2016) posit that the nitrogen fertilization and spatial arrangement of plants are 
also important factors to consider when attempting to increase water use efficiency, as well as nourish plants and improve the productivity of plant distributions.

Analyzing cotton crops' water use and water use efficiency in a changing climate, Luo et al. (2015) have observed a decrease in cotton yield and overall productivity in future climate scenarios; this decline is due to the expected increase in the duration of drought periods and increase in air temperature. Studies aimed at developing strategies to maximize yield components are very important and will become increasingly important as the climate changes; for example, in order to increase the productivity of agricultural crops such as maize and beans, research must be conducted regarding water use efficiency. This research is especially important, due to a lack of studies about water use efficiency for corn and beans when they are cultivated in second crop systems.

It is important to understand and quantify the processes that involve the relationship between meteorological elements and a plant's response, especially with respect to water, in order to implement measures to reduce the impact of drought on the productivity these species. This study aimed to evaluate the water use efficiency and production response of corn and beans when subjected to a range of water levels, cultivated in secondary crop systems.

\section{Results and Discussion}

\section{Meteorological characterization and analysis of variance}

Fig 1 describes the mean monthly values of air temperature (minimum, maximum, and mean), solar radiation and precipitation during the experimental conduction period. The air temperature during the bean crop cycle ranged from $3.2^{\circ} \mathrm{C}$ to $35.4^{\circ} \mathrm{C}$, with mean of $21.9^{\circ} \mathrm{C}$. For corn, the temperature ranged from $2.7^{\circ} \mathrm{C}$ to $35.4^{\circ} \mathrm{C}$, with mean of $21,4^{\circ} \mathrm{C}$. The mean temperature was between 18 to $25^{\circ} \mathrm{C}$ for bean and corn, which was close to the ideal range (Maldaner et al., 2013).

The effective total rainfall $(317.60 \mathrm{~mm})$ was less than the total water requirement for corn, which is 350 to $450 \mathrm{~mm}$ (Bergamaschi et al., 2004) and close to the minimum necessary for bean, which is 300 to $500 \mathrm{~mm}$ (Doorembos and Kassam, 1979). We verified low levels cumulative rainfall in March and May, the periods of lowest rainfall corresponded to approximately 40 and 70 days after the first emergence of the corn and bean cultures, respectively. We observed that the drought occurred in stages which corresponds to the flowering and ripening of beans, and grain filling in corn. It is known that proper plant distribution during the crop cycle is of fundamental importance for the proper development of plants.

The observed results are consistent with those of Barnaby et al. (2013) who report that the water stress during the grain filling period affect the growth of corn plants, and especially influence the relations between leaf water, net $\mathrm{CO}_{2}$ assimilation rates, and foliar metabolite levels. According to Müller et al. (2014), drought stress, particularly during flowering and grain-filling stages of growth, contributes to serious yield losses in bean plants. Global climate change is predicted to increase ambient temperatures as well as the frequency and severity of drought in various growing regions that are highly dependent on maize (Campos et al., 2004; Sicher et al., 2011). Plant breeders and major seed companies have developed maize genotypes with enhanced yields in water deficient environments.

According to the analysis of variance, there was a significant difference $(p<0.05)$ for the water use efficiency and grain yield in both crops, and yield components: number of pods per plant, number of seeds per pod and thousand grain mass for bean and number of grains per row for corn.

\section{Grain yield and yield components of bean}

When analyzing the influence of water levels on crop yield components, there was a linear correlation to the number of pods per plant (Fig 2). This may be associated with more ideal plant-development conditions. The treatments that offered the greatest water availability favored the flowering of these species, and resulted in greater retention of flowers and pod formation. This resulting number of pods per plant with well-formed grains is similar to results obtained in a study by Ávila et al. (2010) working with cultivated beans in a secondary crop system, where they observed number of pods per plant equal to 21 and 13 with and without irrigation, respectively.

Greater water demand of the beans occured during flowering, and extended to grain filling, and coincided with a greater leaf area index and increased photosynthetic activity. At this stage of development, crop evapotranspiration can reach values above $6 \mathrm{~mm} \mathrm{day}^{-1}$ (Gomez et al., 2012); thus, the water deficit at this stage can drastically reduce the number of pods per plant. Because of the drought conditions observed in the treatment without irrigation, stress occurred in the flowering period. Around 40 days after emergence, flower senescence was observed resulted in a reduction of $60 \%$ of pods per plant compared to the higher applied water levels. According to Silva et al. (2007), in drought conditions the beans plants often experience a reduction in flowering time, with a reduction in the period of production and accumulation of assimilates.

There was positive linear correlation in the number of grains per pod in the treatments with increased water levels (Fig 2). The values seen for the highest water level treatment (3 grains per pod) are similar to values found in other studies with bean irrigated which a range from 3 to 4 (Calvache et al., 1997;. Gomez et al, 2012).

A lower numbers of grains per pod found in the treatment where no addition water was added, this may be related to water deficit in May. According to the station data, the last rainfall occurred on 26 April $(41.40 \mathrm{~mm})$, with no more rain until the completion of the harvest. This period corresponds to the final stage of grain filling and maturation, in which the plant directs assimilates to the grains. Stone and Moreira (2000) reported that the water deficit in reproductive phase promotes reduction in the number of grains per pod, due to the decrease in the percentage of flower retention and grain malformation.

The thousand grain mass responded linearly to increased water availability (Fig 2). The increased grain mass was a related to highest rate of plant growth resulting in greater leaf area, and consequently, in an increased photosynthetic rate for the culture allowing for greater production and direction of assimilates for grain filling. Gomez et al. (2012), working with different water levels in bean crops, found that the thousand grain mass increased linearly with the increase in water levels; they obtained values near $258 \mathrm{~g}$, similar to the value obtained in this study which was $281 \mathrm{~g}$.

This result indicates the need of water for the formation and translocation of soluble substances, such as leaf' assimilates (source) to grains (drain), which are analyzed for total dry matter. According to Boyer (1982), important physiological processes in the grain formation have different sensitivities to water deficits. 
Table 1. Final water consumption of corn and beans in different water level treatments. Frederico Westphalen - RS, Brazil, 2012.

\begin{tabular}{lccccc}
\hline \multirow{2}{*}{ Crop } & \multicolumn{5}{c}{ Water level treatments $(\mathrm{mm})$} \\
\cline { 2 - 5 } & 0 & $50 \%$ ETo & $75 \%$ ETo & $100 \%$ ETo & $125 \%$ ETo \\
\hline Corn & 317.60 & 365.57 & 389.55 & 413.53 & 437.51 \\
Bean & 317.60 & 369.41 & 395.31 & 421.22 & 447.12 \\
\hline
\end{tabular}
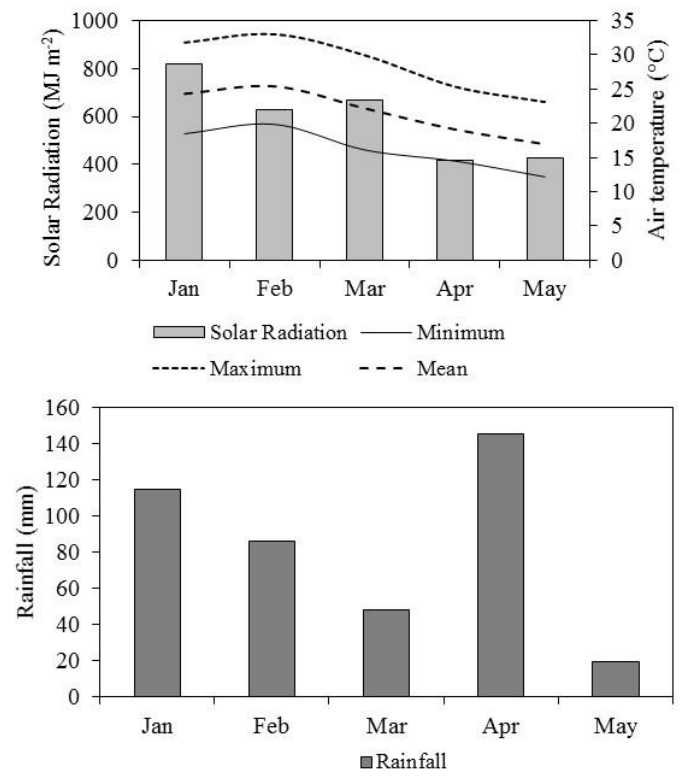

Fig 1. Monthly mean values of minimum, maximum and mean temperature, accumulated incident solar radiation, and monthly rainfall during the experimental period (01/01/2012 to 31/05/2012). Frederico Westphalen - RS, Brazil, 2012.
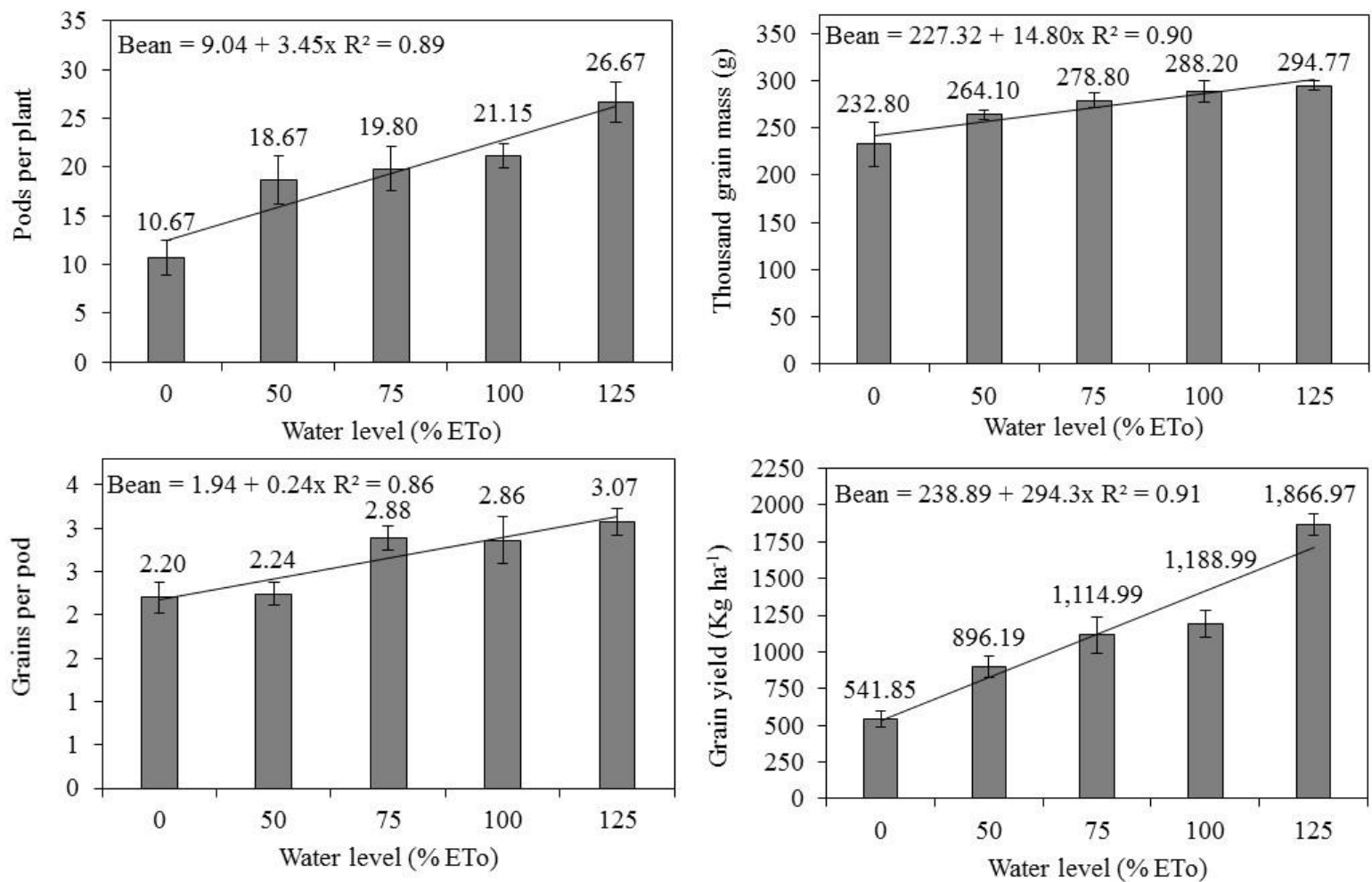

Fig 2. Number of pods per plant, number of grains per pod, thousand grain mass, and yield productivity of the bean under different water level treatments; vertical bars represent the standard error of the means of the measured data. Frederico Westphalen - RS, Brazil, 2012. 

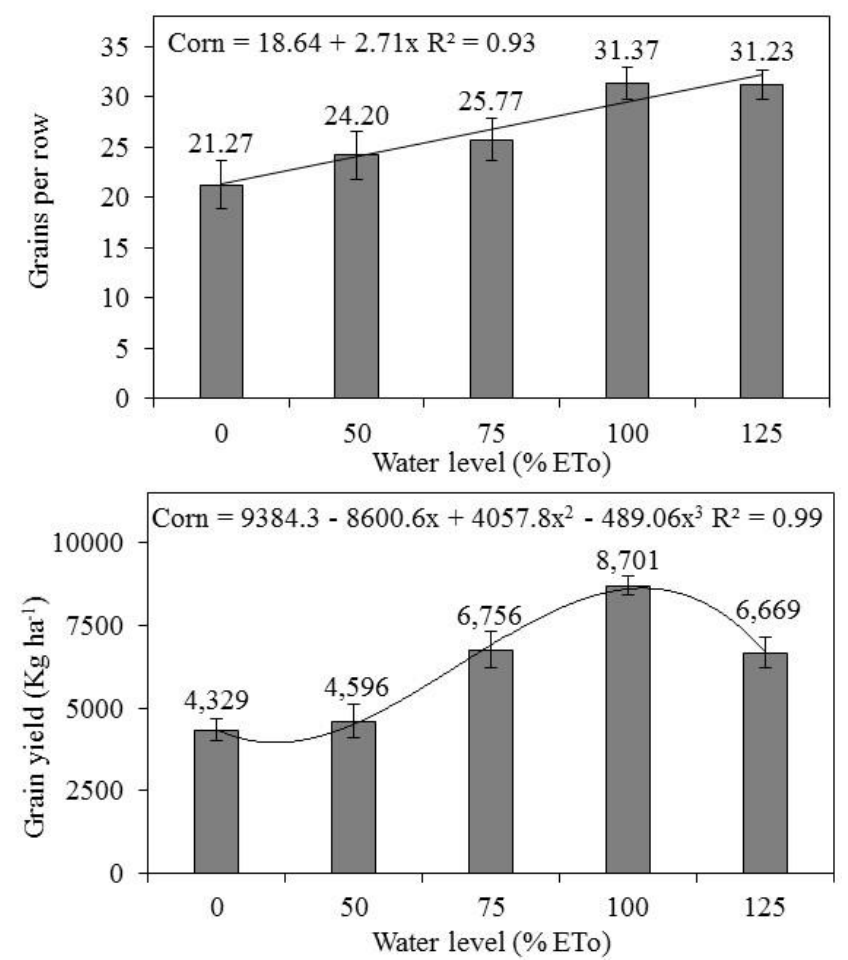

Fig 3. Number of grains per row and grain yield of corn under different water level treatments; vertical bars represent the standard error of the means of the measured data. Frederico Westphalen - RS, Brasil, 2012.
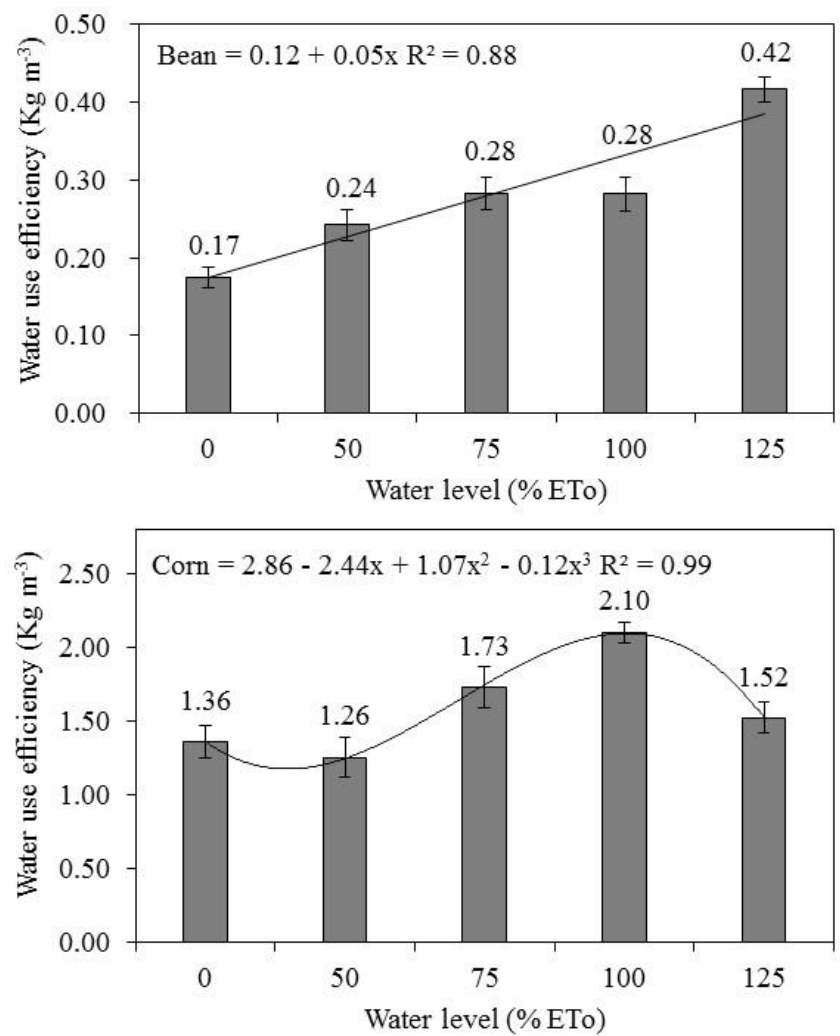

Fig 4. Water use efficiency of bean and corn cultivations under different water levels; vertical bars represent the standard error of the means of the measured data. Frederico Westphalen - RS, Brazil, 2012. 
The number of pods per plant, number of grains per pod, and thousand grain mass are considered the main yield components of bean crops. We observed that the variables had a similar response to the increase of water availability, where the highest values in greater applied water levels was applied (447.12 mm), resulting in higher grain yield (Fig 2). Grain yield, responded linearly to the water levels, this is different from results found by Stone and Moreira (2000), whom observed a quadratic response to the same variables. This demonstrates that the greatest water level applied $(447.12 \mathrm{~mm})$ was not sufficient to achieve maximum productivity. Despite the linear response, productivity achieved by highest water level $\left(1826 \mathrm{~kg} \mathrm{ha}^{-1}\right)$ is similar to those found in the literature which are between 1800 and $2500 \mathrm{~kg} \mathrm{ha}^{-1}$ (Stone and Moreira, 2000; Chieppe Junior et al ., 2007; Santana et al, 2009), in the presence of irrigation. This demonstrates that the greatest applied water levels $(447.12 \mathrm{~mm})$ may be close to what would be considered ideal.

Low yields obtained in the treatment without adding water $\left(684 \mathrm{~kg} \mathrm{ha}^{-1}\right)$ can be explained by water deficit in two crucial stages; at the beginning flowering, and in final grain filling. This fact resulted in reduced grain yield, a lower number of pods per plant and seeds per pod.

Stomata closure due to low water availability conditions may have caused the lower yield. According Paiva et al. (2005), stomatal control is an important physiological process by which plants control the loss of water; it blocks $\mathrm{CO}_{2}$ flow into the leaves, affecting the photosynthetic rate and thus the accumulation of assimilate by a plant which ultimately reduces crop yield.

\section{Total yield and yield components in corn}

When analyzing the influence of water levels in corn, we observed that the number of grains per row showed a linear correlation with increasing water availability (Fig 3). The values for this trait ranged from 21.3 to 31.2 ; the lowest to the highest water levels, respectively. These results are consistent with those found by Silva et al. 2012, whom evaluated the agronomic performance of corn genotypes under drought conditions; they obtained values between 15 and 32 for the number of grains per row, in treatments with and without water restrictions, respectively. Water availability in the soil directly affects the transpiration rate, stomatal conductance, and photosynthesis (Schippers et al., 2015). Because the opening and closing of stomata are controlled by soil water potential, the lack of water affects the photoassimilate production. According to Silva et al. (2012), in drought conditions during the V12 stage (twelve expanded leaves), corn crop water demand was not met, and therefore saw stomatal closure and decreased levels photosynthesis, reducing overall productivity. Fig 3 shows the grain yield of corn in different water levels. The adjusted equation presented a cubic function, with the highest yields obtained in the value of $100 \%$ Eto $(413.53 \mathrm{~mm})$, corresponding to 8700 $\mathrm{kg} \mathrm{ha}^{-1}$. Comparing the values in the treatment which did not receive irrigation $\left(4328 \mathrm{~kg} \mathrm{ha}^{-1}\right)$, we observed a reduction of $50.26 \%$ in grain yield. Similar results were obtained by Soares et al. (2010), evaluating the productivity of corn grown in different irrigation regimens, they found that the application of a level of $431.5 \mathrm{~mm}$ provided the highest yield $\left(8370 \mathrm{~kg} \mathrm{ha}^{-1}\right)$. In a study conducted by Bergamashi et al. (2004), evaluating a corn crop's yield in two separate years, it was observed that appropriate conditions of rainfall during the critical period of culture, ensured yield close to $8000 \mathrm{~kg}$ $\mathrm{ha}^{-1}$; in contrast, a drought condition during crop development reduced the yield to less than $2000 \mathrm{~kg} \mathrm{ha}^{-1}$.

The effect of water reductions on corn yields is considerable; it becomes necessary to properly control not only the quantity, but the frequency of applied water as well, in order to obtain high grain yields with minimum water consumption. The sensitivity of corn crops to water scarcity, associated with great variability in rainfall distribution during the hot season, makes this factor highly important when considering the risks of cultivation. (Bergamashi et al., 2004). This justifies the high risk that a culture is subjected to, providing a major concern to farmers, even if the meteorological trend is above a region's average mean, such as in years of 'El Niño'.

The amount of overall water applied to a plant, is not the primary factor to be observed in the management of water levels. The proper use of irrigation should be considered in order to obtain greater water use efficiency (Zhou et al., 2015).

\section{Water use efficiency in bean and corn cultures}

Fig 4 describes the data on the water use efficiency of bean and corn crops submitted to different water level treatments. In the case of bean plants, there was a linear correlation in which the water use efficiency increased with the higher water levels in which the greatest WUE $\left(0.41 \mathrm{~mm} \mathrm{~m}^{3} \mathrm{~kg}^{-1}\right)$ was obtained with the level of $125 \%$ Eto (Fig 4). Thus, only the largest water level showed WUE values within the recommended range for the bean crop, which according Doorenbos and Kassam (1979), is from 0.3 to $0.6 \mathrm{~kg} \mathrm{~m}^{-3} \mathrm{~mm}^{-}$ 1. In favorable water conditions, plants have higher conversion of photoassimilates in dry matter per $\mathrm{mm}$ of water, resulting in increased grain yields. Additionally, the absence of water stress allows for increased internal $\mathrm{CO}_{2}$ concentration in leaves due to increased stomatal conductance, increasing the photosynthetic rate (Van der Sleen et al., 2014). Ninou et al. (2012), evaluated the physiological and productive responses of two bean cultures in five levels of irrigation, they found that irrigation system with $100 \%$ Eto provided greater WUE, and found an even greater yield, leaf area, chlorophyll levels in leaves, and net photosynthesis, compared with smaller irrigation systems 50, 25 and $0 \%$ ETO. Taiz and Zeiger (2013), claim that gas exchanges are directly influenced by the weather conditions and that WUE reduction may be strongly associated with solar radiation, temperature variations, and relative humidity. According to Doorenbos and Kassam (1979), the WUE of crops depends mainly on the physical soil conditions, weather, nutritional plant status, physiological factors, genetic nature, and developmental stage. The WUE of corn crops showed cubic responses (Fig 4), and the highest value $\left(2.10 \mathrm{~kg} \mathrm{~m}^{-3} \mathrm{~mm}^{-1}\right)$ was obtained at the level of $100 \%$ Eto, corresponding to the highest grain yield (Fig 2). This indicates that the application of quantities above this level does not result in higher WUE, and leads to an unnecessary waste of water. Similar results were found by Souza et al. (2011), when evaluating the productive response and water use efficiency of corn and beans in a semi-arid region of Brazil. They found that water use efficiency increased with elevated quantities of water, and the higher WUE was obtained with the level $125 \%$ Eto. A study conducted by Abd El wahed et al. (2013), evaluating the response of different irrigation systems on the productivity and water use efficiency in corn, showed values close to $1.40 \mathrm{~kg} \mathrm{~m}^{-3} \mathrm{~mm}^{-1}$. In the results, one can see that when grown in second cropping systems, the corn and beans species responded 
positively to highest water availability, which is a determining factor for plant growth and development. In drought conditions the productive responses of the crops as well as their WUE were affected. In order to increase the water use efficiency of plants and consequently, the direction of assimilates of a grain yield, weather conditions should be taken into account when planning the cultivation of a crop.

\section{Materials and Methods}

\section{Study area}

The study was conducted in the city of Frederico Westphalen - RS, Brazil, at the coordinates $27^{\circ} 23^{\prime} 48^{\prime \prime} \mathrm{S}, 53^{\circ} 25^{\prime} 45^{\prime \prime}$ and an altitude of $490 \mathrm{~m}$. According to Köppen climate classification (Alvares et al., 2013), the climate is Cfa, i.e., humid subtropical with mean annual temperatures of $19.1^{\circ}$ $\mathrm{C}$, and varying maximum and minimum temperatures $38^{\circ} \mathrm{C}$ and $0^{\circ} \mathrm{C}$, respectively. The soil of experimental area was classified as Oxisol typical, with the following physicochemical composition: water $\mathrm{pH}: 6.0 ; \mathrm{P}: 3.0 \mathrm{mg} \mathrm{dm}^{-3} ; \mathrm{K}: 160$ mg dm${ }^{-3}$; Ca: 6,2 $\mathrm{cmol}_{\mathrm{c}} \mathrm{dm}^{-3}$; $\mathrm{Mg}: 3,3 \mathrm{cmol}_{\mathrm{c}} \mathrm{dm}^{-3}$; Al: 0,0 $\mathrm{cmol}_{\mathrm{c}} \mathrm{dm}^{-3}$; CTC: $9,9 \mathrm{cmol}_{\mathrm{c}} \mathrm{dm}^{-3}$; base saturation: $76 \%$ and organic matter: $3.1 \%$. Fertilization occurred in response to the soil analysis; basic fertilization consisted of 40 and $30 \mathrm{~kg}$ $\mathrm{ha}^{-1}$ of nitrogen $(\mathrm{N})$ in the form of urea, 80 and $120 \mathrm{~kg} \mathrm{ha}^{-1}$ of phosphorus $\left(\mathrm{P}_{2} \mathrm{O}_{5}\right)$ as triple superphosphate and 140 and 80 $\mathrm{kg} \mathrm{ha}^{-1}$ of potassium $\left(\mathrm{K}_{2} \mathrm{O}\right)$ in the form of potassium chloride, for corn and beans, respectively. At 20 and 30 days after emergence (DAE), we applied two regimens of $60 \mathrm{~kg} \mathrm{ha}^{-1}$ of urea for corn and $40 \mathrm{~kg} \mathrm{ha}^{-1}$ for the beans.

\section{Experimental design}

Two independent experiments were carried out, one for corn cultivar DKB 240 and another for the bean cultivar IPR Gralha, these cultivars were chosen because they are two of the most commonly planted species in the region. Experimental designs consisted of a randomized single factor block design with five water levels $(0,50,75,100$ and $125 \%$ of reference evapotranspiration; Eto), with three replications. Water demands were determined taking into account the reference evapotranspiration rates Eto $\left(\mathrm{mm} \cdot \mathrm{dia}^{-1}\right)$ for each crop; the rates calculated for the experiment site and were determined by the Penman-Monteith method, described in the report "Study FAO Irrigation and drain 56" (Allen et al., 1998). The meteorological variables of air temperature, precipitation, global radiation, relative humidity, and wind speed were obtained daily by an automatic weather station of national weather institute, located approximately 300 meters from the experiment.

\section{Experimental management}

The application of the water levels was performed manually by using watering cans. The amounts of water required in order to reach each treatment water level were applied after accounting for rainfall during the experimental period. The final water consumption of the cultures at each water level is described in Table 1. The sowing of the corn and beans cultivars occurred manually on January 19, 2012. Seven days after first emergence, the crops were thinned, leaving 10 bean plants $\mathrm{m}^{-1}$ for a total density of 222,000 plants ha ${ }^{-1}$, and 3.5 $\mathrm{m}^{-1}$ corn plants for a final density of 77 thousand plants $\mathrm{ha}^{-1}$. The experimental unit consisted of five $3.0 \mathrm{~m}$ lines, spaced at $0.45 \mathrm{~m}$. We only took measurements from the three central lines, and did not consider plants $0.45 \mathrm{~m}$ from the edges of the treatment area. The experimental procedure was the same for the two studied crops.

\section{Productivity and water-use efficiency analysis}

The harvest of the corn and bean crops was held on 22 and 12 of May, 2012 respectively. The procedures adopted for the grain yield and analysis of the plant components was the same for both cultivars, for all plants of each treatment. Fifteen plants were selected randomly within each experimental unit for the assessment of yield components.

The production variables analyzed for corn were: number of rows per ear (NRE), number of grains per row (NGR), thousand grain mass (TGM, g) and grain yield (YIELD, $\mathrm{kg}$ $\mathrm{ha}^{-1}$ ). For the bean, we evaluated the number of pods per plant (NPP), number of seeds per pod (NSP), thousand grain mass (TGM, g) and grain yield (Yield, $\mathrm{kg} \mathrm{ha}^{-1}$ ). The productivity of each experiment was adjusted for $13 \%$ humidity and then extrapolated to $\mathrm{kg} \mathrm{ha}^{-1}$. Water use efficiency (WUE, $\mathrm{kg} \mathrm{m}^{-3} \mathrm{~mm}^{-1}$ ) was determined by the relationship between grain yield and the applied water level according the expression proposed by Geerts and Raes, (2009): WUE = YIELD/WL, in which YIELD is the grain yield and WL is the accumulated water level $(\mathrm{mm})$.

\section{Statistical analysis}

After collecting and tabulating data, the variance analysis was performed, and the averages of significant variables were grouped and compared by regression analysis for the factor of 'water level', according to the regression analysis at 5\% significance level $(\mathrm{p} \leq 0.05)$; Data were statistically analyzed using the Genes computer program (Cruz, 2013).

\section{Conclusion}

Corn and beans had the highest efficiency of water use at the levels of $100 \%$ and $125 \%$ of Eto (reference evapotranspiration), respectively; this corresponds to the levels which showed the highest grains yield for these crops. When grown in a secondary crop system, the treatment without irrigation reduced the productivity of corn and beans by $50.26 \%$, and $71.09 \%$, respectively. The importance of supplementary water irrigation was established in this study, especially for years with low rainfall. This work involved new research in order to identify strategies aimed at improving methods of cultivation in conjunction with meteorological considerations. Both corn and beans can be recommended for planting in the second crop system as they present a high yield potential under favorable water conditions; in order to meet water demands, they require a total of $413.53 \mathrm{~mm}$ for corn and $447.12 \mathrm{~mm}$ for the bean cultivar distributed throughout the crop cycle.

\section{Acknowledgements}

The authors wish to acknowledge the National Council for Scientific and Technological Development (CNPq - Brazil) and the Coordination for the Improvement of Higher Education Personnel (CAPES - Brazil) for their financial support.

\section{References}

Abd El-wahed MH, Ali EA (2013) Effect of irrigation systems, amounts of irrigation water and mulching on corn 
yield, water use efficiency and net profit. Agric Water Manage. 120:64-71.

Allen RG, Pereira LA, Raes D, Smith M (1998) Crop evapotranspiration (guidelines for computing crop water requirements). Roma: FAO. 297p.

Ávila MR, Barizão DAO, Gomes EP, Fedri G, Albrecht LP (2010) Cultivo do feijoeiro no outono/inverno associado à aplicação de bioestimulante e adubo foliar na presença e ausência de irrigação. Scientia Agrária 11:221-230.

Bergamaschi H, Dalmago GA, Bergonci JI, Bianchi CAM, Müller AG, Comiran F, Heckler BMM (2004) Distribuição hídrica no período crítico do milho e produção de grãos. Pesq Agropec Bras. 39:831-839.

Boyer JS (1982) Plant productivity and environment. Science 218:443-448.

Calvache AM, Reichardt K, Malavolta E, Bacchi OOS (1997) Efeito da deficiência hídrica e da adubação nitrogenada na produtividade e na eficiência do uso da água em uma cultura do feijão. Scientia Agrícola 54:232-240.

Campos H, Cooper M, Habben JE, Edmeades GO, Schussler J R (2004) Improving drought in maize: A view from industry. Field Crop Res. 90:19-34.

Chieppe Junior JB, Pereira AL, Stone LF, Moreira JAA, Klar AE (2007) Efeitos de níveis de cobertura do solo sobre a produtividade e crescimento do feijoeiro irrigado em sistema de plantio direto. Irriga 12:177-184.

CONAB. Companhia Nacional de Abastecimento (2014) Safras / Séries Históricas. <http://www.conab.gov.br.<acesso em 21 Abr. 2015>.

Cruz CD (2013) GENES - a software package for analysis in experimental statistics and quantitative genetics. Acta Sci Agron. 35:271-276.

Cruz JC, Silva GH, Pereira Filho IA, Gontijo Neto MM, Magalhães PC (2011) Sistema de produção de milho safrinha de alta produtividade: Safras 2008 e 2009. Sete Lagoas, Embrapa 10p.

Doorenbos J, Kassam AH (1979) Yield response to water. Roma: FAO. 193p.

Franks PJW, Doheny-Adams T, Britton-Harper ZJ, Gray JE (2015) Increasing water-use efficiency directly through genetic manipulation of stomatal density. New Phytol. 207:188-195.

Geerts S, Raes D (2009) Deficit irrigation as an on-farm strategy to maximize crop water productivity in dry areas. Agric Water Manage. 96:1275-1284.

Gomes EP, Biscaro GA, Ávila MR (2012) Desempenho agronômico do feijoeiro comum de terceira safra sob irrigação na região Noroeste do Paraná. Semina: Ciências Agrárias 33:899-910.

Han K, Han X, Curtis DJ, Kleinman PJ, Wang D, Wang L (2016) Impact of Irrigation, Nitrogen Fertilization, and Spatial Management on Maize. Agron J. 108:1794-1804.

Iqbal MA, Shen YJ, Stricevic R, Pei HW, Sun HY, Amiri E, Penas A, Rio SD (2014) Evaluation of the FAO AquaCrop model for winter wheat on the North China Plain under deficit irrigation from field experiment to regional yield simulation. Agric Water Manage. 135:61-72.

Maldaner LJ, Horing K, Schneider JF, Frigo JP, de Azevedo KD, Grzesiuck AE (2013) Exigência Agroclimática da Cultura do Milho. Rev Bras Energ Renov. 3:13-23.

Müller BSF, Sakamoto T, Silveira RDD, Carvalho PFC, Pereira M, Pappas JGJ, Costa MMC, Guimarães CM, Pereira WJ, Brondani C, Vianello-Brondani, RP (2014) Differentially expressed genes during flowering and grain filling in common bean (Phaseolus vulgaris) grown under drought stress conditions. Plant Mol Biol Rep. 32:438-451.
Ninou E, Tsialtas JT, Dordas CA, Papakosta DK (2012) Effect of irrigation on the relationships between leaf gas exchange related traits and yield in dwarf dry bean grown under Mediterranean conditions. Agric Water Manage. 116:1-7.

Paiva AS, Fernandes EJ, Rodrigues TJD (2005) Condutância estomática em folhas de feijoeiro submetido a diferentes regimes de irrigação. Eng Agríc. 25:161-169.

Puppala N, Fowler JL, Jones TL, Gutschick V, Murray L (2005) Evapotranspiration, yield, and water-use efficiency responses of Lesquerella fendleri at different growth stages. Ind Crops Prod. 21:33-47.

Luo Q, Bange M, Johnston D, Braunack M (2015) Cotton crop water use and water use efficiency in a changing climate. Agric Ecosyst Environ. 202:126-134.

Santana MJ, Silveira AL, Camargos CR, Braga JC (2009) Tensão de água no solo e doses de nitrogênio para a cultura do feijoeiro comum. Irriga 14:518-532.

Schippers P, Sterck F, Vlam M, Zuidema PA (2015) Tree growth variation in the tropical forest: understanding effects of temperature, rainfall and $\mathrm{CO}_{2}$. Glob change biol. 21:2749-2761.

Sicher RC, Kim SH (2011) Advances in Maize, Essential Reviews in Experimental Biology. Society for Experimental Biology, London, 3:373-391.

Silva FB, Ramalho MAP, Abreu AFB (2007) Seleção recorrente fenotípica para florescimento precoce de feijoeiro "Carioca". Pesq Agropec Bras. 42:1437-1442.

Silva MR.D, Martin TN, Ortiz S, Bertoncelli P, Vonz D (2012) Desempenho agronômico de genótipos de milho sob condições de restrição hídrica. Rev de Ciências Agrárias. 35:202-212.

Soares FC, Peiter MX, Robaina AD, Parizi ARC, Vivam G, Ramao C (2010) Resposta da produtividade de hídridos de milho cultivado em diferentes estratégias de irrigação. Irriga 15:36-50.

Soratto RP, Souza-Schlick GDD, Fernandes AM, Oliveira LFFAD (2015) Growth and yield of two common bean cultivars as affected by 2, 3, 5-triiodobenzoic acid rates. Ciênc. Rural. 45:2181-2186.

Souza LD, Moura MD, Sediyama GC, Silva TD (2011) Eficiência do uso da água das culturas do milho e do feijão-caupi sob sistemas de plantio exclusivo e consorciado no semiárido brasileiro. Bragantia 70:715-721.

Stone LF, Moreira JAA (2000) Efeitos de sistemas de preparo do solo no uso da água e na produtividade do feijoeiro. Pesq Agropec Bras. 35:835-841.

Taiz L, Zeiger E (2013) Plant Physiology. 5.ed. Porto Alegre: Artmed, 918p.

Van der Sleen P, Groenendijk P, Vlam M, Anten NP, Boom A, Bongers F, Zuidema PA (2015) No growth stimulation of tropical trees by 150 years of $\mathrm{CO}_{2}$ fertilization but wateruse efficiency increased. Nat Geosci. 8:24-28.

Zhang BC, Huang GB, Li FM (2007) Effect of limited single irrigation on yield of winter wheat and spring maize relay intercropping. Pedosphere 17:529-537.

Zhou XB, Chen YH, Ouyang Z (2015) Spacing between rows: effects on water-use efficiency of double-cropped wheat and soybean. J Agri Sci. 153:90-101. 